\title{
Schoolverlaters tussen onderwijs en arbeidsmarkt 2015. Feiten en cijfers
}

Citation for published version (APA):

Meng, C., \& Sijbers, E. (2016). Schoolverlaters tussen onderwijs en arbeidsmarkt 2015. Feiten en cijfers. ROA. ROA Fact Sheets No. 002 https://doi.org/10.26481/umarof.2016002

Document status and date:

Published: 01/01/2016

DOI:

10.26481/umarof.2016002

Document Version:

Publisher's PDF, also known as Version of record

\section{Please check the document version of this publication:}

- A submitted manuscript is the version of the article upon submission and before peer-review. There can be important differences between the submitted version and the official published version of record.

People interested in the research are advised to contact the author for the final version of the publication, or visit the DOI to the publisher's website.

- The final author version and the galley proof are versions of the publication after peer review.

- The final published version features the final layout of the paper including the volume, issue and page numbers.

Link to publication

\footnotetext{
General rights rights.

- You may freely distribute the URL identifying the publication in the public portal. please follow below link for the End User Agreement:

www.umlib.nl/taverne-license

Take down policy

If you believe that this document breaches copyright please contact us at:

repository@maastrichtuniversity.nl

providing details and we will investigate your claim.
}

Copyright and moral rights for the publications made accessible in the public portal are retained by the authors and/or other copyright owners and it is a condition of accessing publications that users recognise and abide by the legal requirements associated with these

- Users may download and print one copy of any publication from the public portal for the purpose of private study or research.

- You may not further distribute the material or use it for any profit-making activity or commercial gain

If the publication is distributed under the terms of Article $25 \mathrm{fa}$ of the Dutch Copyright Act, indicated by the "Taverne" license above, 
U. Maastricht University in Learning!

Research Centre for Education and the Labour Market | ROA

\section{Schoolverlaters tussen onderwijs en arbeidsmarkt 2015 \\ Feiten en cijfers}

\section{ROA Fact Sheet}

ROA-F-2016/2

Researchcentrum voor Onderwijs en Arbeidsmarkt | ROA Research Centre For Education and the Labour Market / ROA 


\section{Inleiding}

Het ROA verricht jaarlijks onderzoek onder schoolverlaters naar de overgang van school naar arbeidsmarkt of vervolgopleiding. Deze factsheet presenteert in het kort enkele resultaten van de meting die eind 2015 door het ROA is gehouden onder de afgestudeerden van het schooljaar 2013-20I4, dat wil zeggen ongeveer anderhalf jaar na het voltooien van de opleiding. Voor de volledige resultaten wordt verwezen naar het ROA-rapport Schoolverlaters tussen onderwijs en arbeidsmarkt 20I5. In totaal zijn 2I2.II7 gediplomeerde schoolverlaters en afgestudeerden benaderd. De totale respons bedroeg $24 \%$.

De resultaten hebben betrekking op nagenoeg de volle breedte van het onderwijs: vmbo, mbo-bol, mbo-bbl, havo, vwo en hbo. Binnen het mbo wordt er nog onderscheid gemaakt tussen enerzijds de twee verschillende leerwegen (bol en bbl) en anderzijds binnen een leerweg tussen de 4 niveaus. De data in de factsheet zijn geaggregeerd over de onderwijssectoren, maar in de bijlage wordt ook nog een overzicht gegeven van de cijfers per opleidingsniveau gedifferentieerd naar studierichting. De resultaten voor het hbo hebben vanwege de vergelijkbaarheid alleen betrekking op de afgestudeerden van voltijd opleidingen.

De resultaten uit het onderzoek onder de gediplomeerde schoolverlaters en afgestudeerden dienen in de bredere context van de economische situatie gezien worden. De transitie van het onderwijs naar de arbeidsmarkt wordt altijd mede bepaald door de huidige situatie. De wereldwijde financiële crisis, gevolgd door een schuldencrisis in het eurogebied, heeft zijn weerslag op de arbeidsmarkt gemaakt. De invloed van de economische situatie geldt niet alleen voor de indicatoren rechtstreeks gerelateerd aan de arbeidsmarktintrede (bijvoorbeeld werkloosheid of werkzekerheid) maar dit kan ook van invloed zijn op de manier waarop jongeren de afgeronde opleiding beoordelen. De lezer dient hier rekening mee te houden.

\section{Voorbereiding op de arbeidsmarkt}

Middelbare- en hogere beroepsopleidingen dienen jongeren voor te bereiden op een positie op de arbeidsmarkt. Daarnaast dienen opleidingen ook een basis te bieden voor het verder ontwikkelen van kennis en vaardigheden, zowel in de loopbaan als in eventueel vervolgonderwijs. In Tabel I staat het percentage gediplomeerden dat van mening is dat de gevolgde opleiding een (heel) goede basis bood om te starten op de arbeidsmarkt en het percentage gediplomeerden dat van mening is dat de gevolgde opleiding een (heel) goede basis bood om zich verder te ontwikkelen.

Van de mbo-gediplomeerden vindt in totaal $61 \%$ de opleiding een goede basis om hun vaardigheden en kennis

I Uitzondering zijn daarbij de mbo niveau I opleidingen die formeel gezien geen startkwalificatie bieden. verder te ontwikkelen, tegenover $47 \%$ die de opleiding een goede basis voor een start op de arbeidsmarkt vindt. Binnen het mbo valt op dat de mbo-bbl opleidingen hoger scoren (55\%) als basis om te starten op de arbeidsmarkt dan de mbo-bol opleidingen (43\%). Aangezien een mbo-bbl opleiding veel meer werkuren bevat dan een mbo-bol opleiding, is het zeer verklaarbaar dat gediplomeerden van een mbo-bbl opleiding zich beter voorbereid voelen op de arbeidsmarkt. Mbo-bbl opleidingen scoren echter ook hoger op de basis voor het verder ontwikkelen van kennis en vaardigheden (65\%) dan mbo-bol opleidingen (59\%). Binnen het mbo-bol scoren niveau 2 opleidingen het beste op beide onderdelen, en binnen het mbo-bbl niveau 3 opleidingen.

Van de hbo afgestudeerden vind $64 \%$ de opleiding een goede basis om hun vaardigheden en kennis verder te ontwikkelen, tegenover $49 \%$ die de opleiding een goede basis voor een start op de arbeidsmarkt vindt.

\section{Tabel 1}

Opleiding als voorbereiding op de arbeidsmarkt en het verder ontwikkelen van kennis en vaardigheden (\%)

\begin{tabular}{|l|c|c|}
\hline & $\begin{array}{c}\text { Starten op de } \\
\text { arbeidsmarkt } \\
\text { (Heel) goede basis (\%) }\end{array}$ & $\begin{array}{c}\text { Verder ontwikkelen kennis } \\
\text { en vaardigheden } \\
\text { (Heel) goede basis (\%) }\end{array}$ \\
\hline MBO-BOL 1 & 38 & 56 \\
\hline MBO-BOL 2 & 44 & 60 \\
\hline MBO-BOL 3 & 44 & 59 \\
\hline MBO-BOL 4 & 42 & 58 \\
\hline MBO-BBL 1 & 34 & 47 \\
\hline MBO-BBL 2 & 48 & 58 \\
\hline MBO-BBL 3 & 62 & 71 \\
\hline MBO-BBL 4 & 62 & 70 \\
\hline HB0 & 49 & 64 \\
\hline
\end{tabular}

\section{Succes op de arbeidsmarkt}

Het rendement in economische termen van een opleiding hangt af van verschillende factoren bij de start in de arbeidsmarkt. Daarom is de arbeidsmarktintrede van gediplomeerden van het mbo en afgestudeerden van het hbo op verschillende indicatoren onderzocht.

Figuur I laat de werkloosheid op enquêtemoment voor de verschillende opleidingstypes zien van 2002 tot 2015. De invloed van de conjunctuur op de werkeloosheid is duidelijk zichtbaar in het figuur. Zowel de economische crisis van 2002-2005 als de economische crisis die in 2009 begon is zichtbaar door een stijging in de werkeloosheid. Tussen 2008 en 2014 zijn onder de invloed van de meest recente crisis de werkeloosheidspercentages voor mbo-bol gediplomeerden verdrievoudigd (van $4 \%$ in 2008 naar bijna $13 \%$ in 20I4), voor mbo-bbl gediplomeerden zelfs verzesvoudigd (van $\mathrm{I} \%$ in 2008 naar $6 \%$ in 2014) en voor hbo afgestudeerden is het werkeloosheidspercentage meer dan verdubbeld (van $3 \%$ in 2008 naar $7 \%$ in 20I4). Hoewel in 2014 er ook al een lichte krimp in de werkloosheid voor de hbo afgestudeerden zat (-o,7\%-punt), is in 2015 een sterke daling in de werkloos- 
heidscijfers zichtbaar. Voor mbo-bol gediplomeerden is het werkloosheidspercentage met I,8\%-punt gezakt naar II\%, voor mbo-bbl gediplomeerden zakte het zelfs met $2,2 \%$ punt naar $4 \%$ en voor hbo afgestudeerden met $\mathrm{I}, 3 \%$-punt naar $6 \%$.

\section{Figuur 1}

Werkloosheid op enquêtemoment (\%)

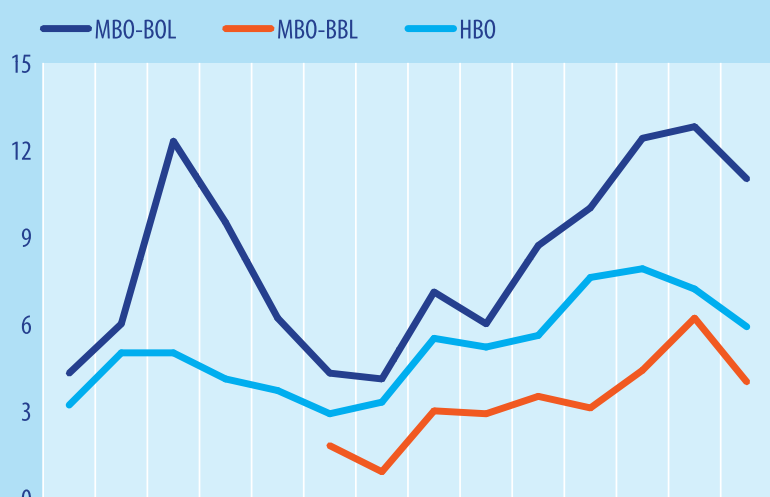

020022003200420052006200720082009201020112012201320142015

Het werkloosheidspercentage op het enquêtemoment zegt echter niet alles over hoe soepel de intrede op de arbeidsmarkt verlopen is. Daarom zijn in Figuur 2 cijfers met betrekking tot de zoekduur naar de eerste baan opgenomen.

Het is zichtbaar dat gediplomeerden van het mbo-bol langer moeten zoeken naar hun eerste baan dan gediplomeerden van het mbo-bbl. Gemiddeld genomen over alle 4 de opleidingsniveaus had $20 \%$ van de mbo-bol gediplomeerden te maken met intredewerkloosheid tegenover $9 \%$ bij mbo-bbl gediplomeerden. Deze resultaten zijn mogelijk te wijten aan het feit dat bbl-gediplomeerden veelal in dienst treden bij het bedrijf waar ze hun opleiding hebben gevolgd.

Ook tussen de verschillende niveaus binnen de mboopleidingen is een verschil in de zoekduur naar de eerste baan waar te nemen. In de regel geldt dat hoe hoger het niveau van de opleiding is, des te hoger de kans om zonder intredewerkloosheid een baan te vinden. Binnen het mbo-bol is te zien dat gediplomeerden van niveau I de meeste last van intredewerkloosheid hebben (26\%, waarbij $17 \%$-punt zelfs langer dan 3 maanden werkloos is $)^{2}$, gevolgd door niveau 2 (24\%, waarbij $17 \%$-punt langer dan 3 maanden), niveau 3 (2I\%, waarbij I2\%-punt langer dan 3 maanden) en niveau 4 (I8\%, waarbij II\%-punt zelfs langer dan 3 maanden). Binnen het mbo-bbl hebben gediplomeerden van niveau 2 het meeste last van intredewerkloosheid ( $13 \%$, waarbij $7 \%$-punt langer dan 3 maanden), gevolgd door niveau I (IO\%, waarbij $7 \%$-punt langer dan 3 maanden), niveau 3 (8\%, waarbij $4 \%$-punt langer dan 3 maanden) en niveau 4 ( $7 \%$, waarbij $3 \%$-punt langer dan 3 maanden).

In figuur 2 is verder te zien dat afgestudeerden van het hbo in verhouding nog het meeste last hadden van intrede- werkloosheid. Maar liefst 32\% van de afgestudeerde hbo'ers had last van intredewerkloosheid, tegenover I6\% van de gediplomeerde mbo'ers. Hiervan is I $4 \%$ I tot 3 maanden aan het zoeken naar de eerste baan, $13 \% 4$ tot 12 maanden en nog $5 \%$ zelfs I 3 maanden of langer. Een mogelijke verklaring voor de hogere intredewerkloosheid van hbo'ers is dat zij mogelijk kritischer zijn bij het zoeken naar een functie en nadrukkelijker de wens hebben om een baan te vinden die goed bij het niveau en de richting van de gevolgde studie aansluit dan mbo'ers.

Figuur 2

Intredewerkloosheid (\%)

OMND. 1-3 MND.

100
80
60

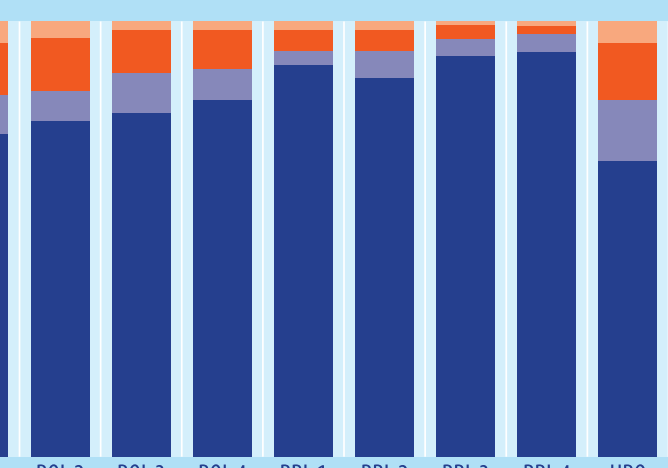

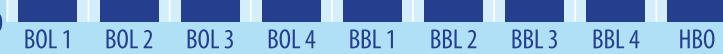

Naast werkloosheidscijfers zijn er nog enkele andere belangrijke indicatoren die een beeld geven van de aansluiting tussen onderwijs en arbeidsmarkt. Figuur 3 laat zien hoe goed het werk van schoolverlaters aansluit bij hun afgeronde opleiding wat betreft niveau en richting. Onder de afgestudeerden van het mbo is het $71 \%$ dat een baan op minimaal het eigen opleidingsniveau heeft, waarbij bblgediplomeerden vaker een baan op minstens het eigen niveau heeft $(72 \%)$ dan bol-gediplomeerden (71\%). Bij het hbo heeft gemiddeld $77 \%$ een baan op minstens het eigen niveau.

Naast het niveau van de functie is ook de richting van de functie van belang om iets te kunnen zeggen over de kwaliteit van de baan. Uit Figuur 3 blijkt dat gediplomeerde schoolverlaters van het laagste niveau binnen het mbo het minst vaak werkzaam zijn binnen het eigen beroepsdomein. Het vaakst werkzaam binnen het eigen beroepsdomein zijn gediplomeerden van niveau 4 (bol niveau $474 \%$ en bbl niveau $485 \%$ ), en het minst vaak gediplomeerden van niveau I (bol niveau I 6I\%, bbl niveau I 47\%). Van de hbo'ers werkt $77 \%$ in de eigen of verwante richting. 
Figuur 3

Aansluiting werk op afgeronde opleiding

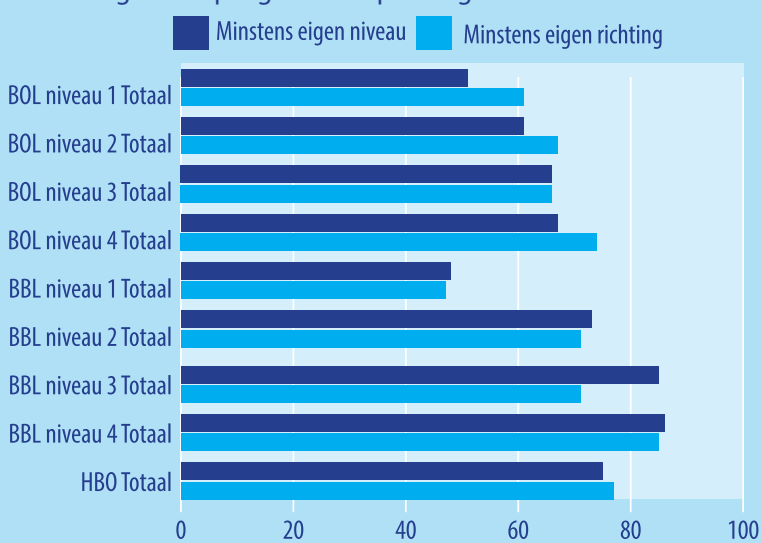

Als aanvulling op deze objectieve indicatoren is de ansluiting van het onderwijs op de arbeidsmarkt ook vastgesteld door middel van een meer subjectieve manier, namelijk door de respondenten te vragen hoe tevreden ze zelf zijn over de aansluiting tussen hun functie en de door hun gevolgde opleiding.

Overwegend kan gesteld worden dat mbo-bbl gediplomeerden tevredener zijn dan mbo-bol gediplomeerden. Bij het mbo-bbl vindt $83 \%$ van de gediplomeerden de aansluiting voldoende tot goed, en bij het mbo-bol $68 \%$. Afgestudeerden van het hbo zitten hierbij iets boven het mbo-bol: $72 \%$ beoordeelt de aansluiting voldoende of goed.

\section{Figuur 4}

Aansluiting gevolgde opleiding en huidige functie (\%)

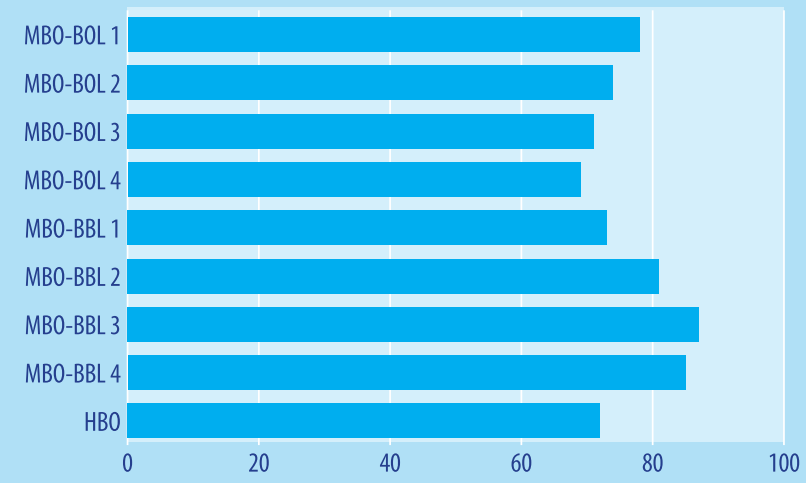

Een andere indicator voor de kwaliteit van het werk en de transitie tussen onderwijs en arbeidsmarkt is de beloning die werkzame schoolverlaters ontvangen. In Tabel 2 wordt per opleidingsniveau het gemiddelde bruto uurloon weergegeven. Het uurloon biedt een eerlijkere vergelijking dan het maandloon, omdat verschillen in het maandloon ook veroorzaakt kunnen worden door het aantal gewerkte uren.

Voor zowel het mbo-bol als het mbo-bbl geldt in de regel dat hoe hoger het behaalde opleidingsniveau is, hoe hoger het uurloon is. Gemiddeld is het uurloon van mbo-bol gediplomeerden lager $(€ 9,08)$ dan het uurloon van mbo-bbl gediplomeerden $(€ \mathrm{II}, 97)$. Bij de gediplomeerden van bol varieert het bruto uurloon tussen $€ 6,39$ (niveau I) en $€$ 9,82 (niveau 4) en bij de gediplomeerden van bbl tussen $€$ IO,25 (niveau I) en $€ \mathrm{I3}, 94$ (niveau 4). Het gemiddelde uurloon van hbo afgestudeerden ligt hoger $(€ \mathrm{I} 3,3 \mathrm{I})$ dan die van het mbo-bol of mbo-bbl. De enige onderliggende uitzondering hierop is dat mbo-bbl 4 gediplomeerden een hoger uurloon verdienen $(€ \mathrm{I} 3,94)$ dan hbo-gediplomeerden $(€ \mathrm{I} 3,3 \mathrm{I})$.

Tabel 2

Gemiddelde bruto uurloon $(€)$

\begin{tabular}{|l|r|}
\hline MBO-BOL 1 & uurloon \\
\hline MBO-BOL 2 & 6,39 \\
\hline MBO-BOL 3 & 7,47 \\
\hline MBO-BOL 4 & 9,04 \\
\hline MBO-BBL 1 & 9,82 \\
\hline MBO-BBL 2 & 10,26 \\
\hline MBO-BBL 3 & 10,36 \\
\hline MBO-BBL 4 & 12,51 \\
\hline HBO & 13,94 \\
\hline Uurloon afgerond op 5 eurocent & 13,31
\end{tabular}

\section{Tevredenheid met functie}

Hoewel alle besproken onderdelen een belangrijke indicator zijn van het succes van de opleiding en de startersfunctie, is de tevredenheid van de schoolverlaters met hun huidige functie misschien nog wel het belangrijkste. Deze tevredenheid wordt gemeten op twee indicatoren, namelijk de algemene tevredenheid met de huidige functie en de tevredenheid met carrièreperspectieven die de functie biedt. In Tabel 3 wordt per opleidingsniveau de tevredenheid met de huidige functie en de tevredenheid met carrièreperspectieven die de functie biedt weergegeven.

Hbo afgestudeerden zijn overwegend het meest tevreden met hun huidige functie: Tweederde (66\%) is tevreden met zijn of haar huidige functie en nog eens $57 \%$ vindt dat zijn of haar huidige functie goede carrièreperspectieven biedt. Binnen het mbo zijn bbl gediplomeerden net iets tevredener over hun huidige functie (68\%) dan bol gediplomeerden (66\%). De gediplomeerden van niveau I zijn het minst tevreden over hun huidige functie, zowel bij het mbo-bol (6I\%) als het mbo-bbl (58\%).

Tabel 3

Tevredenheid met huidige functie en carrièreperspectieven (\%)

\begin{tabular}{|l|r|r|r|r|r|r|r|r|r|} 
& BOL & BOL & BOL & BOL & BBL & BBL & BBL & BBL & HBO \\
\hline $\begin{array}{l}\text { Tevreden met functie } \\
\text { Goede }\end{array}$ & 61 & 66 & 65 & 66 & 58 & 68 & 70 & 70 & 66 \\
\hline $\begin{array}{l}\text { carrièreperspectieven } \\
47\end{array}$ & 48 & 48 & 50 & 27 & 48 & 52 & 53 & 57 \\
\hline
\end{tabular}

\section{Doorstroom naar vervolgopleiding}

$\mathrm{Na}$ het behalen van hun diploma kunnen jongeren er voor kiezen om een vervolg te geven aan hun onderwijsloopbaan in plaats van zich direct aan te bieden op de arbeidsmarkt. In Figuur 5 staat een overzicht van de kwalificerende 
vervolgtrajecten van de gediplomeerde schoolverlaters uit het onderzoek.

De doorstroom naar het vervolgonderwijs neemt af naarmate het niveau van het behaalde certificaat toeneemt. Het vmbo wordt niet als een startkwalificatie gezien, en dit blijkt ook uit de doorstroom van $97 \%$ naar een vervolgonderwijs. De doorstroom is voornamelijk naar een mbo-bol opleiding $(75 \%)$, en voor een deel naar een mbo-bbl opleiding (I2\%). Daarnaast stroomt nog een deel (9\%) door naar de havo. $\mathrm{Na}$ het behalen van een mbo-bol diploma, gaat nog $57 \%$ een volgende opleiding volgen: 30\%-punt gaat naar een hbo-opleiding, 22\%-punt naar een andere mbo-bol opleiding en $5 \%$-punt naar een mbo-bbl opleiding. Vanuit het mbo-bbl gaan er minder verder leren dan vanuit het mbo-bol, maar dit is nog steeds $22 \%$. De meeste kiezen voor een andere mbo-bbl opleiding erachteraan ( $15 \%)$, maar ook $3 \%$ gaat een mbo-bol opleiding volgen en nog eens $3 \%$ naar een hbo-opleiding.

Vanuit de havo gaat $92 \%$ door met een vervolgopleiding. Verreweg de meeste kiezen een hbo-opleiding als vervolg op hun havo diploma (85\%), maar ook nog $4 \%$ kiest voor een mbo-bol opleiding en $\mathrm{I} \%$ gaat door naar het vwo. Vanuit het vwo gaat $96 \%$ verder leren na het diploma. Het merendeel kiest voor een wo-opleiding $(80 \%)$, en ook een deel voor een hbo-opleiding ( $15 \%)$. De gediplomeerden van de havo of het vwo die niet gaan verder leren verlaat in de regel slechts tijdelijk het onderwijs, aangezien velen van hen een sabbatical nemen en een jaar gaan reizen of andere plannen hebben voordat ze met hun vervolgopleiding starten.

Vanuit het hbo besluit ook nog eens een kwart (26\%) een volgende opleiding te gaan volgen. De meeste kiezen voor een wo-opleiding (I6\%), maar ook een andere hboopleiding $(5 \%)$ komt voor.

\section{Figuur 5}

Kwalificerende vervolgtrajecten na het verlaten studie

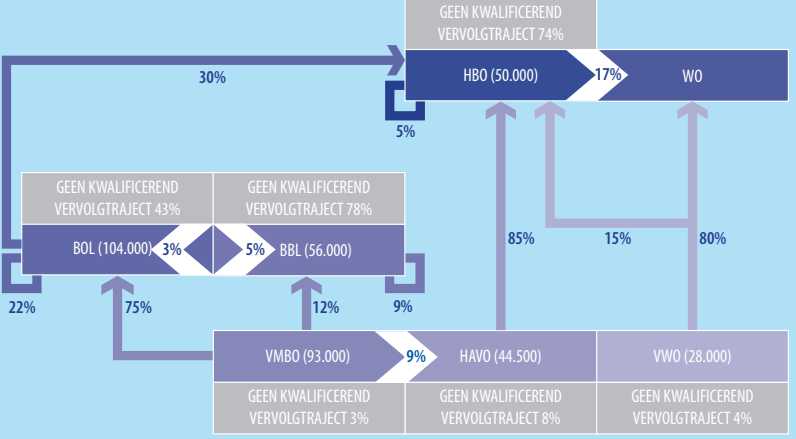

Aan de schoolverlaters die doorstromen naar een vervolgopleiding is gevraagd hoe zij de aansluiting beoordelen tussen de voltooide opleiding en de vervolgopleiding. Figuur 6 geeft weer welk deel van de verder lerende schoolverlaters deze aansluiting voldoende of goed vindt. De overgrote meerderheid van de doorstromers naar een vervolgopleiding (77\%) is van mening dat de aansluiting tussen de eerder gevolgde opleiding en de vervolgopleiding voldoende tot goed is.
Bij het middelbaar onderwijs beoordelen vwo gediplomeerden hun opleiding het beste ( $85 \%$ is tevreden) en vmbo gediplomeerden beoordelen de aansluiting het minst als voldoende ( $78 \%$ is tevreden). Aangezien het vmbo een opleiding is zonder startkwalificatie en een vervolgopleiding een logische volgende stap is, zou de aansluiting tussen het vmbo en het vervolgonderwijs niet tekort mogen schieten.

Binnen het mbo is te zien dat mbo-bol gediplomeerden overwegend kritischer zijn over de aansluiting dan mbo-bbl gediplomeerden. Over alle niveaus samen vinden $82 \%$ van de mbo-bbl gediplomeerden en 70\% van de mbo-bol gediplomeerden de aansluiting voldoende. Binnen het mbo valt op dat de hogere niveaus minder tevreden zijn over de aansluiting dan de lagere niveaus. Is bij niveau I nog $80 \%$ (mbo-bbl I) en $88 \%$ (mbo-bbl I) tevreden, bij niveau 4 is er nog slechts 66\% (mbo-bbl 4 ) en 60\% (mbo-bol 4 ) tevreden. Hierbij dient er rekening mee gehouden te worden dat voor de gediplomeerden van de lagere mbo-bol opleidingen de doorstroom naar een vervolgopleiding in de regel binnen het mbo plaatsvindt, terwijl doorleren voor de gediplomeerden van het mbo niveau 4 in de regel een overstap naar het hbo betekent.

Vanuit het hbo is $73 \%$ tevreden over de aansluiting op het vervolgonderwijs, waarmee het hbo tussen het mbo-bol (70\%) en mbo-bbl $(82 \%)$ in zit.

\section{Figuur 6}

Aansluiting voltooide opleiding en vervolgopleiding (\%)

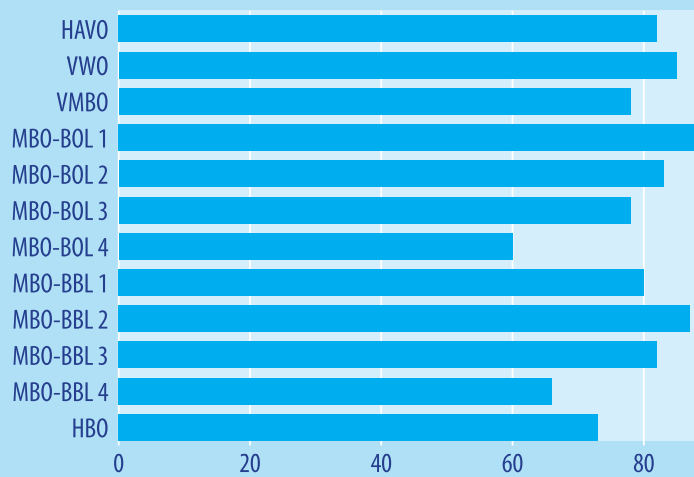

Om meer inzicht te krijgen in het succes van een vervolgopleiding laat Figuur 7 zien welk deel van de jongeren de het percentage dat op moment van enquêtering (ongeveer anderhalf jaar na het behalen van het diploma) de vervolgopleiding (voortijdig) heeft verlaten. Hierbij wordt er een onderscheid gemaakt tussen studiewisselaars (gestopt met de studie maar meteen met een andere begonnen) en netto uitval (verdwenen uit het vervolgonderwijs).

Onder de gediplomeerden van het middelbaar onderwijs die met een vervolgopleiding zijn gestart komen de meeste studiewisselaars voor bij de havo (I2\%), gevolgd door het vwo-ers $(7 \%)$ en het vmbo-ers $(4 \%)$. De meeste netto uitval binnen het voortgezet onderwijs komt voor bij de havisten die een vervolgopleiding zijn gaan doen (3\%), gevolgd door vmbo-ers (2\%) en de vwo-ers (I\%).

Onder de gediplomeerden van het mbo is te zien dat er bij de gediplomeerden van het mbo-bol die een vervolg- 
opleiding zijn gaan doen meer studiewisselaars voorkomen dan bij de gediplomeerden van het mbo-bbl die verder zijn gaan leren. Bij de gediplomeerden van het mbo-bol die verder zijn gaan leren wisselt nog $4 \%$ van studie, bij het mbo-bbl (nagenoeg) niemand (o\%). De netto uitval is bij het mbo-bol ook hoger $(6 \%)$ dan bij het mbo-bbl (4\%). Onder de afgestudeerden van het hbo die verder zijn gaan studeren is er sprake van $5 \%$ uitval en (nagenoeg) geen studiewisselaars (०\%).

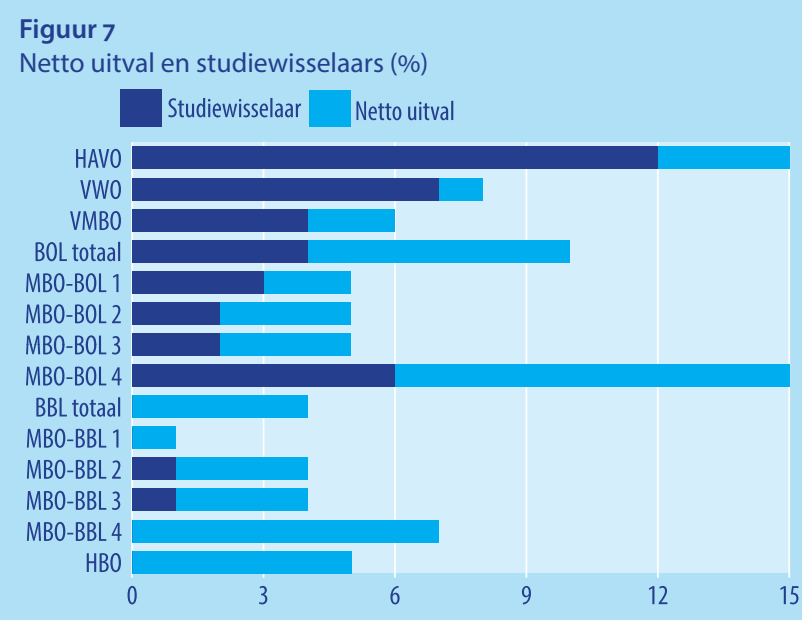

\section{Tevredenheid opleiding}

Op basis van verschillende indicatoren is de tevredenheid van de schoolverlaters over de door hun gevolgde opleiding gemeten. Hierbij is zowel naar inhoudelijke onderwijszaken (zoals de inhoud van de vakken, manier van lesgeven) als naar meer materiële en praktische aspecten (zoals voorzieningen) gekeken.

Als samenvattend oordeel is de gediplomeerden gevraagd of ze achteraf gezien opnieuw voor dezelfde opleiding zouden kiezen (zie Tabel 4). Van alle gediplomeerde schoolverlaters zou $82 \%$ dezelfde opleiding weer opnieuw kiezen. Dit percentage laat zien dat de overgrote meerderheid van de respondenten nog steeds achter de door hun gemaakte studiekeuze staan. Het avo scoort hierbij het hoogst, waar maar liefst $98 \%$ dezelfde opleiding opnieuw zou kiezen.

Binnen het mbo zijn gediplomeerden van het mbo-bbl relatief vaker tevreden met hun opleiding dan gediplomeerden van het mbo-bol. Over alle niveaus samengenomen zou $84 \%$ van alle mbo-bbl gediplomeerden dezelfde opleiding opnieuw kiezen, tegenover $76 \%$ van alle mbo-bol gediplomeerden. Binnen het mbo zijn de gediplomeerden van de hogere niveaus achteraf bezien vaker tevreden over hun keuze dan gediplomeerden van de lagere niveaus. Op niveau 4 is $78 \%$ (mbo-bol) en $85 \%$ (mbo-bbl) tevreden, op niveau I nog 71\% (mbo-bol) en $76 \%$ (mbo-bbl). Vervolgens zijn afgestudeerden van het hbo met ruim driekwart ook tevreden over hun opleidingskeuze: hier zou $78 \%$ achteraf bezien dezelfde opleiding kiezen.

Tabel 4

Tevredenheid achteraf (\%)

\begin{tabular}{|l|r|r|}
\hline & \multicolumn{2}{|c|}{$\begin{array}{c}\text { Opleidingskeuze } \\
\text { Dezelfde opleiding }\end{array}$} \\
\hline AVO & 98 & Andere opleiding \\
\hline VMB0 & 87 & 13 \\
\hline MBO-BOL 1 & & \\
\hline MBO-BOL 2 & 71 & 29 \\
\hline MBO-BOL 3 & 73 & 27 \\
\hline MBO-BOL 4 & 75 & 25 \\
\hline MBO-BBL 1 & 78 & 22 \\
\hline MBO-BBL 2 & & 24 \\
\hline MBO-BBL 3 & 76 & 18 \\
\hline MBO-BBL 4 & 82 & 14 \\
\hline HBO & 86 & 15 \\
\hline Totaal & 85 & 22 \\
\hline
\end{tabular}




\section{Algemeen}

\begin{tabular}{|c|c|c|c|}
\hline & $\begin{array}{l}\text { Opleiding goede basis om te starten op } \\
\text { arbeidsmarkt (\%) }\end{array}$ & $\begin{array}{l}\text { Opleiding goede basis voor verder } \\
\text { ontwikkelen van kennis en vaardigheden (\%) }\end{array}$ & $\begin{array}{l}\text { Opleiding achteraf } \\
\text { opnieuw kiezen (\%) }\end{array}$ \\
\hline VMBO & 27 & 57 & 87 \\
\hline VMBO theoretische leerweg & 22 & 59 & 88 \\
\hline VMBO landbouw & 26 & 53 & 88 \\
\hline VMBO techniek & 33 & 60 & 81 \\
\hline VMBO economie & 39 & 61 & 85 \\
\hline VMB0 gezondheidszorg & 34 & 59 & 89 \\
\hline VMBO intersectoraal & 20 & 45 & 88 \\
\hline MBO & 47 & 61 & 79 \\
\hline BOL & 43 & 59 & 76 \\
\hline BOL 1 & 38 & 56 & 71 \\
\hline BOL 2 & 44 & 60 & 73 \\
\hline BOL 2 landbouw & 47 & 59 & 80 \\
\hline BOL 2 techniek & 46 & 60 & 78 \\
\hline BOL 2 economie & 44 & 59 & 70 \\
\hline BOL 2 gezondheidszorg & 41 & 62 & 71 \\
\hline BOL 3 & 44 & 59 & 75 \\
\hline BOL 3 landbouw & 49 & 57 & 78 \\
\hline BOL 3 techniek & 51 & 64 & 80 \\
\hline BOL 3 economie & 39 & 55 & 70 \\
\hline BOL 3 gezondheidszorg & 54 & 65 & 80 \\
\hline BOL 3 gedrag en maatschappij & 40 & 57 & 74 \\
\hline BOL 4 & 42 & 58 & 78 \\
\hline BOL 4 landbouw & 44 & 51 & 71 \\
\hline BOL 4 techniek & 48 & 61 & 79 \\
\hline BOL 4 economie & 38 & 56 & 78 \\
\hline BOL 4 gezondheidszorg & 52 & 64 & 83 \\
\hline BOL 4 gedrag en maatschappij & 34 & 57 & 76 \\
\hline$B B L$ & 55 & 65 & 84 \\
\hline BBL 1 & 34 & 47 & 76 \\
\hline BBL 2 & 48 & 58 & 82 \\
\hline BBL 2 landbouw & 42 & 53 & 84 \\
\hline BBL 2 techniek & 50 & 58 & 85 \\
\hline BBL 2 economie & 47 & 58 & 78 \\
\hline BBL 2 gezondheidszorg & 44 & 59 & 78 \\
\hline BBL 3 & 62 & 71 & 86 \\
\hline BBL 3 landbouw & 57 & 65 & 88 \\
\hline BBL 3 techniek & 62 & 70 & 88 \\
\hline BBL 3 economie & 48 & 61 & 79 \\
\hline BBL 3 gezondheidszorg & 75 & 81 & 88 \\
\hline BBL 3 gedrag en maatschappij & 53 & 67 & 84 \\
\hline
\end{tabular}




\section{Algemeen}

\begin{tabular}{|c|c|c|c|}
\hline & $\begin{array}{l}\text { Opleiding goede basis om te starten op } \\
\text { arbeidsmarkt (\%) }\end{array}$ & $\begin{array}{l}\text { Opleiding goede basis voor verder } \\
\text { ontwikkelen van kennis en vaardigheden (\%) }\end{array}$ & $\begin{array}{l}\text { Opleiding achteraf } \\
\text { opnieuw kiezen (\%) }\end{array}$ \\
\hline BBL 4 & 62 & 70 & 85 \\
\hline BBL 4 landbouw & 46 & 59 & 71 \\
\hline BBL 4 techniek & 65 & 74 & 86 \\
\hline BBL 4 economie & 52 & 61 & 82 \\
\hline BBL 4 gezondheidszorg & 70 & 77 & 89 \\
\hline BBL 4 gedrag en maatschappij & 48 & 61 & 76 \\
\hline HBO & 49 & 64 & 78 \\
\hline HBO landbouw & 59 & 70 & 77 \\
\hline HBO techniek & 60 & 68 & 84 \\
\hline HBO economie & 50 & 63 & 72 \\
\hline HBO gezondheidszorg & 52 & 67 & 84 \\
\hline HBO gedrag en maatschappij & 38 & 61 & 74 \\
\hline $\mathrm{HBO}$ onderwijs & 54 & 60 & 86 \\
\hline HBO taal en cultuur & 29 & 71 & 84 \\
\hline Totaal & 41 & 60 & 82 \\
\hline
\end{tabular}

Bron: ROA (SIS) 


\section{Vervolgopleiding}

\begin{tabular}{|c|c|c|c|}
\hline & $\begin{array}{l}\text { Aansluiting } \\
\text { redelijk/goed (\%) }\end{array}$ & $\begin{array}{c}\text { Netto uitval } \\
\text { in vervolgopleiding (\%) }\end{array}$ & $\begin{array}{c}\text { Studiewisselaar } \\
\text { in vervolgopleiding (\%) }\end{array}$ \\
\hline HAVO/VWO & 83 & 2 & 10 \\
\hline HAVO & 82 & 3 & 12 \\
\hline Vwo & 85 & 1 & 7 \\
\hline VMBO & 78 & 2 & 4 \\
\hline VMBO theoretische leerweg & 78 & 0 & 5 \\
\hline VMBO landbouw & 77 & 3 & 4 \\
\hline VMBO techniek & 73 & 0 & 3 \\
\hline VMBO economie & 78 & 6 & 1 \\
\hline VMBO gezondheidszorg & 72 & 4 & 5 \\
\hline VMBO intersectoraal & 78 & 5 & 7 \\
\hline MBO & 72 & 6 & 3 \\
\hline $\mathrm{BOL}$ & 70 & 6 & 4 \\
\hline BOL 1 & 88 & 2 & 3 \\
\hline BOL 2 & 83 & 3 & 2 \\
\hline BOL 2 landbouw & 77 & 2 & 2 \\
\hline BOL 2 techniek & 83 & 2 & 2 \\
\hline BOL 2 economie & 81 & 3 & 1 \\
\hline BOL 2 gezondheidszorg & 87 & 4 & 2 \\
\hline BOL 3 & 78 & 3 & 2 \\
\hline BOL 3 landbouw & 74 & 7 & 2 \\
\hline BOL 3 techniek & 78 & 6 & 1 \\
\hline BOL 3 economie & 77 & 3 & 2 \\
\hline BOL 3 gezondheidszorg & 81 & 3 & 1 \\
\hline BOL 3 gedrag en maatschappij & 75 & 4 & 1 \\
\hline BOL 4 & 60 & 8 & 6 \\
\hline BOL 4 landbouw & 53 & 9 & 4 \\
\hline BOL 4 techniek & 61 & 9 & 4 \\
\hline BOL 4 economie & 61 & 9 & 7 \\
\hline BOL 4 gezondheidszorg & 62 & 8 & 3 \\
\hline BOL 4 gedrag en maatschappij & 57 & 8 & 6 \\
\hline BBL & 82 & 4 & 0 \\
\hline BBL 1 & 80 & 1 & 0 \\
\hline BBL 2 & 87 & 3 & 1 \\
\hline BBL 3 & 82 & 3 & 1 \\
\hline BBL 4 & 66 & 7 & 0 \\
\hline
\end{tabular}




\section{Vervolgopleiding}

\begin{tabular}{|c|c|c|c|}
\hline & $\begin{array}{c}\text { Aansluiting } \\
\text { redelijk/goed (\%) }\end{array}$ & $\begin{array}{c}\text { Netto uitval } \\
\text { in vervolgopleiding (\%) }\end{array}$ & $\begin{array}{c}\text { Studiewisselaar } \\
\text { in vervolgopleiding (\%) }\end{array}$ \\
\hline HBO & 73 & 6 & 0 \\
\hline HBO landbouw & 72 & 5 & 0 \\
\hline HBO techniek & 70 & 8 & 1 \\
\hline HBO economie & 72 & 7 & 0 \\
\hline HBO gezondheidszorg & 77 & 5 & 0 \\
\hline HBO gedrag en maatschappij & 73 & 8 & 0 \\
\hline $\mathrm{HBO}$ onderwijs & 80 & 3 & 0 \\
\hline HBO taal en cultuur & - & 5 & 0 \\
\hline Totaal & 77 & 4 & 5 \\
\hline
\end{tabular}

Bron: ROA (SIS) 


\title{
Arbeidsmarkt
}

$\begin{array}{cccccc}\begin{array}{c}\text { Minimaal op eigen } \\ \text { niveau (\%) }\end{array} & \begin{array}{c}\text { Eigen/verwante } \\ \text { richting (\%) }\end{array} & \begin{array}{c}\text { Aansluiting } \\ \text { voldoende/goed (\%) }\end{array} & \begin{array}{c}\text { Werkloos } \\ (\%)\end{array} & \begin{array}{c}\text { Intrede werkloosheid } \\ >3 \text { mnd. (\%) }\end{array} & \begin{array}{c}\text { Bruto uurloon } \\ \text { (euro) }\end{array}\end{array}$

\begin{tabular}{l|}
\hline MBO \\
\hline BOL \\
\hline BOL 1 \\
\hline BOL 2 \\
\hline BOL 2 landbouw \\
\hline BOL 2 techniek \\
\hline BOL 2 economie \\
\hline BOL 2 gezondheidszorg
\end{tabular}

71

28

\begin{abstract}
77
\end{abstract}
8

9

10,49

$71 \quad 35$

70

11

9,08

$61 \quad 49$

78

30

6,39

$67 \quad 61$

$62 \quad 54$

$72 \quad 64$

BOL 2 gezondheidszorg

$63 \quad 57$

BOL 3

BOL 3 landbouw

$66 \quad 66$

BOL 3 techniek

58

BOL 3 economie

63

BOL 3 gezondheidszorg

BOL 3 gedrag en maatschappij

$76 \quad 76$

72

BOL 4

BOL 4 landbouw

74

BOL 4 techniek

72

BOL 4 economie

BOL 4 gezondheidszorg

BOL 4 gedrag en maatschappij

1
5
7
7
6

74
76
75
75
71

$\begin{array}{lll}16 & 17 & 7,47 \\ 16 & 14 & 6,49 \\ 14 & 16 & 8,07 \\ 15 & 17 & 7,34 \\ 18 & 18 & 7,13\end{array}$

BBL

72

BBL 1

47

48

71

$11 \quad 12$

9,04

56

72

66

80

72

$13 \quad 8,40$

3

73

$\begin{array}{lll}12 & 14 & 10,03 \\ 16 & 16 & 8,24\end{array}$

$\begin{array}{lll}12 & 14 & 10,03 \\ 16 & 16 & 8,24\end{array}$

BBL 2

BBL 2 landbouw

$\begin{array}{ll}71 & 73 \\ 68 & 71\end{array}$

BBL 2 techniek

$70 \quad 75$

BBL 2 economie

68

BBL 2 gezondheidszorg

76

BBL 3

BBL 3 landbouw

BBL 3 techniek

BBL 3 economie

$B B L 3$ gezondheidszorg

BBL 3 gedrag en maatschappij

$71 \quad 85$

$\begin{array}{ll}71 & 85 \\ 67\end{array}$

$\begin{array}{ll}67 & 87\end{array}$

$\begin{array}{ll}57 & 69\end{array}$

$83 \quad 94$

$\begin{array}{ll}87 & 88\end{array}$

\section{BBL 4}

BBL 4 landbouw

$85 \quad 86$

BBL 4 techniek

73

BBL 4 economie

BBL 4 gezondheidszorg

BBL 4 gedrag en maatschappij

72

94

89

86
72
90
70
96
84

84

76
9
6
4

$$
69
$$$$
14
$$$$
9,61
$$$$
9,31
$$

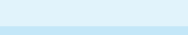

$\begin{array}{llll}83 & 4 & 5 & 11,97 \\ 73 & 9 & 7 & 10,26\end{array}$

73
71
75
64
80

$\begin{array}{cccc}81 & 5 & 7 & 10,36 \\ 83 & 7 & 6 & 10,23 \\ 81 & 4 & 4 & 10,43 \\ 80 & 9 & 12 & 9,17 \\ 86 & 4 & 7 & 11,91\end{array}$

-1
85
8
8
8

87
84
84
82
92
86

$\begin{array}{lcc}3 & 4 & 12,51 \\ 3 & 3 & 12,10 \\ 2 & 3 & 12,82 \\ 4 & 6 & 10,66 \\ 2 & 2 & 13,45 \\ 6 & 10 & 13,16\end{array}$




\section{Arbeidsmarkt}

$\begin{array}{cccccc}\text { Minimaal op eigen } & \text { Eigen/verwante } & \text { Aansluiting } & \text { Werkloos } & \text { Intrede werkloosheid } & \text { Bruto uurloon } \\ \text { niveau (\%) } & \text { richting (\%) } & \text { voldoende/goed (\%) } & (\%) & >3 \text { mnd. (\%) } & \text { (euro) }\end{array}$

\begin{tabular}{|c|c|c|c|c|c|c|}
\hline HBO & 77 & 75 & 72 & 6 & 18 & 13,31 \\
\hline HBO landbouw & 79 & 74 & 74 & 8 & 21 & 12,90 \\
\hline HBO techniek & 85 & 81 & 75 & 6 & 16 & 14,23 \\
\hline HBO economie & 80 & 66 & 67 & 7 & 20 & 13,10 \\
\hline HBO gezondheidszorg & 81 & 88 & 81 & 3 & 17 & 14,72 \\
\hline HBO gedrag en maatschappij & 55 & 76 & 68 & 6 & 23 & 12,96 \\
\hline HBO onderwijs & 89 & 90 & 84 & 4 & 14 & 13,65 \\
\hline HBO taal en cultuur & 67 & 62 & 69 & 7 & 20 & 10,41 \\
\hline Totaal $^{1}$ & 69 & 73 & 76 & 7 & 12 & 9,92 \\
\hline
\end{tabular}

${ }^{1}=$ inclusief $\mathrm{VMBO}$

Bron: ROA (SIS) 


\section{Trendcijfers werkloosheid}

$\begin{array}{lcccccccccccc} & 2004 & 2005 & 2006 & 2007 & 2008 & 2009 & 2010 & 2011 & 2012 & 2013 & 2014 & 2015 \\ \text { MBO-BOL 1/2 } & 23 & 19 & 11 & 8 & 8 & 12 & 12 & 16 & 16 & 21 & 22 & 18 \\ \text { MBO-BOL 3/4 } & 8 & 6 & 5 & 2 & 3 & 5 & 4 & 6 & 8 & 10 & 10 & 9 \\ \text { MBO-BBL 1/2 } & 5 & 6 & 3 & 3 & 1 & 4 & 4 & 5 & 4 & 6 & 7 & 6 \\ \text { MBO-BBL 3/4 } & 4 & 2 & 2 & 1 & 1 & 2 & 2 & 2 & 2 & 3 & 5 & 3 \\ \text { HBO } & 5 & 4 & 4 & 3 & 3 & 5 & 5 & 6 & 8 & 8\end{array}$

-: Niet beschikbaar

Toelichting: Het jaartal heeft betrekking op het meetjaar. In 2012 is het cohort 2010-2011 bevraagd.

Opmerking: In de metingen van $2000 \mathrm{t} / \mathrm{m} 2002$ betreft het schoolverlaters van MAVO/VBO. Vanaf de meting 2003 betreft het schoolverlaters van VMBO. 


\section{Schoolverlatersinformatiesysteem}

\section{Een openbaar toegankelijke bron van data}

\section{Algemeen}

De subsidiemiddelen beschikbaar gesteld door het Ministerie van Onderwijs, Cultuur en Wetenschap, het Ministerie van Economische Zaken en het Ministerie van Sociale Zaken en Werkgelegenheid maken de basisvoorziening mogelijk (dataverzameling, technisch databeheer en algemene methoden- en modellenstudies). De databestanden zijn daarbij vrij toegankelijk en maken daarmee een breed pallet van strategisch onderzoek mogelijk, van proefschriften, wetenschappelijke beleidsrelevante artikelen tot landelijke beleidsrapportages. De jaarlijkse databestanden afkomstig van het SchoolverlatersInformatieSysteem zijn beschikbaar via www.dans.knaw.nl. Via het Researchcentrum voor Onderwijs en Arbeidsmarkt kunnen onderzoekers eveneens kosteloos een Engelstalig trendbestand (metingen 1998 20I5) opvragen. Voor ondersteuning bij het gebruik van de databestanden zijn de onderzoekers van het ROA bereikbaar via secretary-roa-sbe@maastrichtuniversity.nl

Cijfers afkomstig van het SchoolverlatersInformatieSysteem zijn recent onder andere gebruikt voor: ${ }^{1}$

- Studiekeuze I23 website;

- Studie in cijfers;

- Keuzegids MBO, Keuzegids HBO;

- Onderwijs in Cijfers van het Ministerie van OCW

- Onderwijsinspectie: De staat van het onderwijs onderwijsverslag;

- Onderwijsinspectie: Beginnende leraren kijken terug, deel I: de pabo

- Onderwijsinspectie: Beginnende leraren kijken terug, deel 2: de Tweedegraads Lerarenopleidingen

- SEO/ECBO/ROA: Klaar voor de groei: Monitor uitrol Associate degree

- $\mathrm{MBO}$ raad: Feiten en cijfers;

- ECBO: Het Nederlandse onderwijs geketend: Doorstroom in en tussen vo en mbo;

- ECBO: De kleur van het middelbaar beroepsonderwijs: Een overzichtsstudie naar allochtonen in het mbo;

- Innovatieplatform: Kennis en Innovatie Agenda 2OII - 2020;

- SCP, Jaarrapport Integratie, 20I3.
Website Kerncijfers Schoolverlatersonderzoeken: https://roastatistics.maastrichtuniversity.nI/SISOnline/Home. aspx

Op de website Kerncijfers Schoolverlatersonderzoeken (https://roastatistics.maastrichtuniversity.nl/SISOnline/ Home.aspx) zijn meerjarige landelijke statistieken te vinden over gediplomeerde schoolverlaters van het initiële onderwijs in Nederland. De cijfers zijn gebaseerd op de schoolverlatersonderzoeken van het ROA en hebben betrekking op de gediplomeerden van het avo, vmbo, mbo en het ho. De kerncijfers die gepresenteerd worden geven een inzicht in de gevolgde studie, het vervolgonderwijs en de intrede van de schoolverlaters op de arbeidsmarkt.

De website is te raadplegen vanuit twee invalshoeken: naar onderwijsindeling en naar kernindicator. De invalshoek naar onderwijs laat alle kerncijfers voor een bepaalde onderwijsindeling zien. Hierbij kan gekozen worden voor onderwijsniveaus, onderwijssectoren en individuele opleidingen. Daarnaast is er de mogelijkheid om een keuze te maken voor voltijd, deeltijd of duale opleidingsvarianten. De invalshoek naar indicator laat voor alle onderwijsniveaus, - sectoren dan wel opleidingen de informatie over één gekozen indicator zien. Zowel in het menu als in de overzichtstabellen zijn de kernindicatoren naar een vijftal categorieën ingedeeld:

- algemene achtergrondkenmerken;

- gevolgde opleiding;

- oordeel over de gevolgde opleiding;

- kenmerken vervolgonderwijs;

- arbeidsmarktindicatoren en baankenmerken.

De cijfers worden telkens weergegeven voor de laatste vijf meetjaren en worden jaarlijks geupdate rond de tijd dat het landelijk rapport 'Schoolverlaters tussen Onderwijs en Arbeidsmarkt' uitkomt.

De website biedt daarnaast uitgebreide informatie over de methodologische aanpak van het Schoolverlatersinformatiesysteem (SIS) alsmede een verantwoording van de respons. 


\section{Colofon}

(C) Researchcentrum voor Onderwijs en Arbeidsmarkt (ROA). Niets uit deze uitgave mag op enige manier worden verveelvoudigd zonder voorafgaande schriftelijke toestemming van de directeur van het ROA.

\section{Researchcentrum voor Onderwijs en Arbeidsmarkt}

Maastricht University

School of Business and Economics

secretary-roa-sbe@maastrichtuniversity.nl

www.roa.nl

Vormgeving

ROA secretariaat, Maastricht

juli 2016 
Researchcentrum voor Onderwijs en Arbeidsmarkt

Postbus 616

6200 MD Maastricht

$\mathrm{T}+31433883647$

F +31 433884914

secretary-roa-sbe@maastrichtuniversity.nl

www.roa.nl

Maastricht University

School of Business and Economics 